\title{
R-Plasmid-mediated Chromosome Mobilization in the Facultative Methylotroph Pseudomonas AM1
}

\author{
By P. K. TATRA AND P. M. GOODWIN* \\ Department of Biological Sciences, North East Surrey College of Technology, Reigate Road, \\ Ewell, Surrey KTI7 3DS, U.K.
}

(Received 2 March 1983; revised 28 April 1983)

Chromosomal genes of the facultative methylotroph, Pseudomonas AM1, have been mobilized using the broad host-range plasmid, R68.45. Genes coding for $\mathrm{C}_{1}$ metabolism were transferred at a frequency of $10^{-5}$ to $10^{-4}$ per donor cell. The genes coding for resistance to cycloserine, phosphonomycin and streptomycin are linked to the methanol dehydrogenase gene, while the marker for thiamin auxotrophy is not.

\section{INTRODUCTION}

The genetics of methylotrophic bacteria have not been extensively studied because there are few methods available for transferring chromosomal genes between genetically marked strains of these organisms. O'Connor \& Hanson (1978) used transformation to study linkage of $\mathrm{C}_{1}$ utilization genes in Methylobacterium organophilum. Two investigations of the genetics of methylotrophs have made use of broad host-range plasmids. Gautier \& Bonewald (1980) cloned the wild-type methanol dehydrogenase gene of Pseudomonas AM1 in Escherichia coli using plasmid R1162. The methanol dehydrogenase gene was then transferred to a methanol dehydrogenase mutant of Pseudomonas AM1, using RP4 to mobilize the hybrid plasmid. Moore et al. (1983) developed a method of 'complementation mapping' in Methylophilus methylotrophus using $\mathbf{R}^{\prime}$ derivatives of $\mathrm{pM} 1072$.

Some broad host-range plasmids can mobilize the chromosomes of many Gram-negative bacteria (Holloway, 1979). One such plasmid, R68.45 (Haas \& Holloway, 1976), which codes for resistance to kanamycin, tetracycline and $\beta$-lactam antibiotics, has been used to map the chromosomes of several genera (Beringer \& Hopwood, 1976; Sistrom, 1977; Casadesus \& Olivares, 1979; Hamada et al., 1979; Megias et al., 1982). This plasmid has been transferred to several methylotrophs (Jeyaseelan \& Guest, 1979; Warner et al., 1980), but chromosome mobilization was not demonstrated in these studies.

In this paper we demonstrate that R68.45 can mobilize the chromosome of the facultative, serine-pathway methylotroph Pseudomonas AM1, and present some preliminary data on gene linkage in this organism.

\section{METHODS}

Bacterial strains. The bacterial strains used are shown in Table 1.

Media and growth of organisms. Pseudomonas aeruginosa PAO8 carrying R68.45 was grown in nutrient broth (Oxoid no. 2) containing $0.5 \%(\mathrm{w} / \mathrm{v})$ yeast extract and kanamycin $\left(500 \mu \mathrm{g} \mathrm{ml}^{-1}\right)$, and was maintained on agar slopes of the same medium. Mutant strains of Pseudomonas AM1 were grown in minimal salts medium (MacLennan et al., 1971) with either $0.2 \%(\mathrm{w} / \mathrm{v})$ sodium succinate or $0.2 \%(\mathrm{v} / \mathrm{v})$ methanol as carbon source, and were maintained on agar slopes of the same medium. Where appropriate, the medium was supplemented with thiamin $\left(5 \mu \mathrm{g} \mathrm{ml}^{-1}\right)$ or adenine $\left(20 \mu \mathrm{g} \mathrm{ml}^{-1}\right)$. Strains of Pseudomonas AMl carrying R68.45 were grown and maintained on media containing kanamycin.

All antibiotics were added as filter-sterilized aqueous solutions to the growth media at the following final concentrations: kanamycin, $500 \mu \mathrm{g} \mathrm{m}^{-1}$ for $P$. aeruginosa and $200 \mu \mathrm{g} \mathrm{m}^{-1}$ for Pseudomonas AM1; streptomycin, $200 \mu \mathrm{g} \mathrm{ml}^{-1}$; D-cycloserine, $250 \mu \mathrm{g} \mathrm{ml}^{-1}$; phosphonomycin, $300 \mu \mathrm{g} \mathrm{ml}^{-1}$. 
Table 1. Bacterial strains and plasmids

Plasmid/Strains

Plasmid R68.45

Donors

Pseudomonas aeruginosa PAO8(R68.45)

Pseudomonas AM1 PT1(R68.45)

Pseudomonas AM1 PT2(R68.45)

Recipients

Pseudomonas AM1 PG1-1

Pseudomonas AM1 PG1-2

Pseudomonas AM1 PG1-3

Pseudomonas AM1 PCT48-1
Relevant properties

IncP $\mathrm{Km}^{\mathrm{R}} \mathrm{Tc}^{\mathrm{R}} \mathrm{Cb}^{\mathrm{R}}$

$\mathrm{Ilv}^{-} \mathrm{Met}^{-} \mathrm{Str}^{\mathrm{R}}$

Ade $^{-}$

$\mathrm{Thi}^{-}$

Methanol dehydrogenase ${ }^{-} \mathbf{S t r}^{\mathbf{R}}$ Methanol dehydrogenase ${ }^{-} \mathrm{Pho}^{\mathrm{R}}$ Methanol dehydrogenase ${ }^{-} \mathrm{Cyc}^{\mathrm{R}}$ Serine pathway mutant $\operatorname{Str}^{R}$

\section{Reference}

Haas \& Holloway (1976)

Haas \& Holloway (1976)

This paper

This paper

This paper

This paper

This paper

Dunstan et al. (1972)

Isolation of mutants. Mutants of Pseudomonas AM1 unable to grow on $\mathrm{C}_{1}$ compounds were isolated by the method of Heptinstall \& Quayle (1970), using $N$-methyl- $N^{\prime}$-nitro- $N$-nitrosoguanidine as the mutagen. Auxotrophic mutants were isolated by the same method. Antibiotic-resistant strains were isolated either by selecting for spontaneous mutants or by treatment of exponential-phase cultures with $N$-methyl- $N^{\prime}$-nitro- $N$ nitrosoguanidine followed by isolation of resistant clones. PT1 and PT2 were made auxotrophic before R68.45 was transferred to them.

Mating procedures. The antibiotic agar overlay method of Jeyaseelan \& Guest (1979) was used to transfer plasmid R68.45 from P. aeruginosa to Pseudomonas AM1.

The patch mating method of Johnston et al. (1978) was used to screen clones for the ability to mobilize the chromosome, and was modified as follows to estimate frequencies of transfer of chromosomal markers. Lateexponential phase cultures of donor and recipient strains were mixed $(1: 1)$ at an approximate concentration of $10^{8}$ cells $\mathrm{ml}^{-1}$ and mated on nutrient agar plates for $36 \mathrm{~h}$. The growth was harvested from the surface of the plates and the cells were washed twice in sterile $0.9 \%(w / v)$ saline. A significant loss of bacteria occurred during the harvesting and washing stages. The bacteria were resuspended in $2 \mathrm{ml}$ sterile $0.05 \mathrm{M}$-potassium phosphate buffer, $\mathrm{pH} 7 \cdot 2$, and $0.1 \mathrm{ml}$ was plated in triplicate on to selective media to estimate the number of recombinants. The numbers of viable donor and recipient cells were determined on appropriate media. Sterile $0.9 \%(w / v)$ saline containing $0.01 \%(\mathrm{v} / \mathrm{v})$ Nonidet P40 (BDH) (a nonionic detergent used to minimize clumping) was used as diluent. Recombinant clones were tested for unselected markers by streaking on to appropriate media; between 200 and 300 clones were tested from each mating.

\section{RESULTS AND DISCUSSION}

Plasmid R68.45 was transferred from $P$. aeruginosa to Pseudomonas AM1 at an average frequency of $10^{-6}$ transconjugants per recipient cell. Clones of Pseudomonas AM1(R68.45) were screened for their ability to transfer the genes coding for methanol utilization to recipients unable to grow on methanol. Of 1238 clones tested, $37(3 \%)$ had chromosome mobilizing ability.

The frequency of transfer of the genes coding for methanol utilization was estimated using two auxotrophic strains, PT1 (Ade ${ }^{-}$) and PT2 (Thi ${ }^{-}$), as donors. Antibiotic-resistant strains of PG1, which lacks methanol dehydrogenase, and PCT48, which is probably blocked in the Iclpart of the serine pathway (i.e. in the conversion of acetyl-CoA to glyoxylate, which does not involve isocitrate lyase; Dunstan et al., 1972), were recipients. The frequency of transfer of the genes coding for methanol utilization was in the range $10^{-5}-10^{-4}$ per donor cell.

Linkage of the genes coding for $\mathrm{C}_{1}$ utilization and antibiotic resistance was investigated by testing recombinant clones for the unselected donor markers. When PG1 was used as recipient, cycloserine sensitivity was transferred with the methanol dehydrogenase gene in over $95 \%$ of the recombinants (Table 2), indicating that these markers are closely linked. The genes coding for methanol dehydrogenase and phosphonomycin sensitivity were transferred together in almost $90 \%$ of the recombinants but the methanol dehydrogenase gene and the streptomycin sensitivity marker did not show such close linkage, being cotransferred in only $65-72 \%$ of the recombinants. When PCT48 was the recipient, the wild-type allele of the serine pathway gene which was defective in this mutant was transferred with the streptomycin sensitivity marker more frequently, with about $80 \%$ of the recombinants containing both donor markers. 


\section{Table 2. Cotransfer of chromosomal markers of Pseudomonas AMI}

Recipients which had received the donor markers which determined methanol utilization were selected initially. The selective medium contained no growth factors, thus preventing growth of the donor strains. Recombinant clones were tested for the unselected donor markers as described in Methods.

$\begin{array}{rlcccc}\text { Donor } & \text { Recipient } & \begin{array}{c}\text { Unselected } \\ \text { marker }\end{array} & \begin{array}{c}\text { No. of recombinants } \\ \text { expressing both } \\ \text { donor markers }\end{array} & \begin{array}{c}\text { No. of } \\ \text { recombinants } \\ \text { tested }\end{array} & \begin{array}{c}\text { Percentage of } \\ \text { recombinants } \\ \text { expressing both } \\ \text { donor markers }\end{array} \\ \text { PT1 } & \text { PG1-1 } & \mathrm{Str}^{\mathrm{s}} & 194 & 300 & 65 \\ \text { PT1 } & \text { PG1-2 } & \mathrm{Pho}^{\mathrm{S}} & 240 & 270 & 89 \\ \text { PT1 } & \text { PG1-3 } & \mathrm{Cyc}^{\mathrm{S}} & 291 & 300 & 97 \\ \text { PT2 } & \text { PG1-1 } & \mathrm{Str}^{\mathrm{S}} & 177 & 246 & 72 \\ \text { PT2 } & \text { PG1-2 } & \mathrm{Pho}^{\mathrm{S}} & 234 & 262 & 89 \\ \text { PT2 } & \text { PG1-3 } & \mathrm{Cyc}^{\mathrm{S}} & 270 & 270 & 100 \\ \text { PT2 } & \text { PCT48-1 } & \mathrm{Str}^{\mathrm{S}} & 241 & 290 & 83\end{array}$

\section{Table 3. Frequency of isolation of recombinants of Pseudomonas AM1 on different selective} media when PT2 was used as donor

No growth was detected when either the donors or the recipients were plated on to the selective media. Abbreviations: Str, streptomycin; Pho, phosphonomycin; Cyc, D-cycloserine; Thi, thiamin.

\begin{tabular}{cllccc} 
Donor & Recipient & \multicolumn{1}{c}{ Selective medium } & $\begin{array}{c}\text { No. of } \\
\text { recombinants } \\
\mathrm{ml}^{-1}\end{array}$ & $\begin{array}{c}\text { No. of } \\
\text { donors } \\
\mathrm{ml}^{-1}\end{array}$ & $\begin{array}{c}\text { Frequency of } \\
\text { recombinant isolation } \\
\text { per donor cell }\end{array}$ \\
PT2 & PG1-1 & Methanol + Str & 360 & $1 \cdot 7 \times 10^{6}$ & $2 \cdot 2 \times 10^{-4}$ \\
PT2 & PG1-1 & Methanol + Str + Thi & 450 & $1 \cdot 7 \times 10^{6}$ & $2 \cdot 7 \times 10^{-4}$ \\
PT2 & PG1-2 & Methanol + Pho & 0 & $6 \cdot 7 \times 10^{6}$ & 0 \\
PT2 & PG1-3 & Methanol + Cyc & 0 & $3 \cdot 3 \times 10^{6}$ & 0 \\
PT2 & PCT48-1 & Methanol + Str & 375 & $5 \times 10^{6}$ & $7 \cdot 5 \times 10^{-5}$ \\
PT2 & PCT48-1 & Methanol + Str + Thi & 378 & $5 \times 10^{6}$ & $7 \cdot 5 \times 10^{-5}$
\end{tabular}

The frequency of recombinant isolation on different selective media in the crosses between PT2 and antibiotic-resistant derivatives of PG1 is shown in Table 3. Recombinants were detected when methanol utilization plus streptomycin resistance were used as selective markers, but not when resistance to either phosphonomycin or cycloserine were the counterselected markers. This confirms the conclusion that the genes coding for phosphonomycin and cycloserine resistance are more closely linked to the gene coding for methanol dehydrogenase than is the streptomycin resistance gene. Approximately $2 \times 10^{-4}$ recombinants were obtained per donor cell when selection was made on methanol plus streptomycin, whether or not thiamin was added to supplement the medium. Furthermore, all recombinants isolated on medium containing thiamin were able to grow in the absence of this vitamin. Similar results were obtained in crosses between PT2 and PCT48. This indicates that the gene determining thiamin auxotrophy in PT2 is not close to the genes coding for $\mathrm{C}_{1}$ metabolism.

We thank the Science Research Council for financial support, Professor I. J. Higgins for the gift of Pseudomonas aeruginosa PAO8(R68.45), and Professor R. Terry and Dr C. Anthony for their advice and encouragement.

\section{REFERENCES}

Beringer, J. E. \& Hopwood, D. A. (1976). Chromosomal recombination and mapping in Rhizobium leguminosarum. Nature, London 264, 291-294.

Casadesus, J. \& Olivares, J. (1979). Rough and fine linkage mapping of the Rhizobium meliloti chromosome. Molecular and General Genetics 174, 203-209.
Dunstan, P. M., Anthony, J. \& Drabble, W. T. (1972). Microbial metabolism of $C_{1}$ and $C_{2}$ compounds. The role of glyoxylate, glycollate and acetate in the growth of Pseudomonas AMI on ethanol and on $C_{1}$ compounds. Biochemical Journal 128, 107-115. GAUTIER, F. \& BonewaLd, R. (1980). The use of R1162 
and derivatives for gene cloning in the methanolutilizing Pseudomonas AM1. Molecular and General Genetics 178, 375-380.

HaAs, D. \& Holloway, B. W. (1976). R-factor variants with enhanced sex factor activity in Pseudomonas aeruginosa. Molecular and General Genetics 144, 243-251.

Hamada, S. E., Luckey, J. P. \& Farrand, S. K. (1979). R-plasmid-mediated chromosomal gene transfer in Agrobacterium tumefaciens. Journal of Bacteriology 130, 280-286.

Heptinstall, J. \& Quayle, J. R. (1970). Pathways leading to and from serine during growth of Pseudomonas AM1 on $\mathrm{C}_{1}$ compounds or succinate. Biochemical Journal 117, 563-572.

Holloway, B. W. (1979). Plasmids that mobilize the bacterial chromosome. Plasmid 2, 1-19.

Jeyaseelan, K. \& Guest, J. R. (1979). Transfer of antibiotic resistance to facultative methylotrophs with plasmid R68.45. FEMS Microbiology Letters 6, 87-89.

Johnston, A. W. B., Setchell, S. M. \& Beringer, J. E. (1978). Interspecific crosses between Rhizobium leguminosarum and $R$. meliloti: formation of haploid recombinants and of R-primes. Journal of General Microbiology 104, 209-218.
Maclennan, D. G., Ousby, J. C., Vasey, R. B. \& Cotton, N. T. (1971). The influence of dissolved oxygen on Pseudomonas AM1 grown on methanol in continuous culture. Journal of General Microbiology 69, 395-404.

Megias, M., Caviedes, M. A., Palomares, A. J. \& Perez-Silva, J. (1982). Use of plasmid R68-45 for constructing a circular linkage map of the Rhizobium trifolii chromosome. Journal of Bacteriology 149, 5964.

Moore, A. T., Nayudu, M. \& Holloway, B. W. (1983). Genetic mapping in Methylophilus methylotrophus AS1. Journal of General Microbiology 129, 785-799.

O’Connor, M. L. \& Hanson, R. S. (1978). Linkage relationships between mutants of Methylobacterium organophilum impaired in their ability to grow on one-carbon compounds. Journal of General Microbiology 104, 105-111.

Sistrom, W. R. (1977). Transfer of chromosomal genes mediated by plasmid R68.45 in Rhodopseudomonas spheroides. Journal of Bacteriology 131, 526-532.

WARNer, P. J., Higgins, I. J. \& DRozD, J. W. (1980). Conjugative transfer of antibiotic resistance to methylotrophic bacteria. FEMS Microbiology Letters 7, 181-185. 